\title{
Comparative study of conventional and microwave-assisted pyrolysis, steam and dry reforming of glycerol for syngas production, using a carbonaceous catalyst
}

\author{
Y. Fernández, A. Arenillas, J.M. Bermúdez, J.A. Menéndez* \\ Instituto Nacional del Carbón, CSIC, Apartado 73, 33080 Oviedo, Spain \\ * Corresponding authors. E-mail address: angelmd@incar.csic.es \\ Tel.: +34 985 18972; Fax: +34 985297672
}

\begin{abstract}
The thermal valorization of glycerol to produce synthesis gas has been investigated under conventional and microwave heating systems. Different processes (pyrolysis, steam reforming and dry reforming) are compared, using a commercial activated carbon as catalyst. The reforming processes that employ oxidizing agents $(\mathrm{CO} 2$ or $\mathrm{H} 2 \mathrm{O})$ were found to promote higher glycerol conversions than mere termal decomposition. Steam reforming generates the lowest gas fraction and the highest amounts of hydrogen and syngas, while the opposite occurs in the dry reforming experiments. Microwave processing produced higher gas yields with large syngas content than conventional heating processes in all cases. The use of carbon-based catalysts appears to be highly suitable for producing synthesis gas with a $\mathrm{H} 2 / \mathrm{CO}$ ratio close to 1 , minimum $\mathrm{CO} 2$ emissions being an additional advantage.
\end{abstract}

\section{Keywords}

Glycerol; Microwave; Carbon-based catalyst; Syngas; Thermal valorization 


\section{Introduction}

In the search for alternatives to the commonly used petroleum derived fuels, biodiesel is one of the most promising renewable transportation-fuels because of its environmental benefits, such as minimal $\mathrm{CO}_{2}$ emissions compared to regular diesel fuels. Moreover it can easily be obtained from inexpensive and readily available feedstocks which serve to increase the added value of biodiesel. The most widespread method of producing biodiesel involves the transesterification of vegetable oils and animal fats, which gives rise to crude glycerol (about $10 \mathrm{wt} \%$ ) as the main by-product.

At the present time, the European Union is the principal biodiesel producer, its production in 2008 increased by $35.7 \%$ compared to 2007 [1]. The rising demand for biodiesel may lead to a glutin the supply of glycerol, which could then be as a feedstock at low or negative cost. The consumption of glycerol at the present rate [2] is not thought to be great enough to use up the entire glicerol surplus. Therefore novel techniques must be developed in order to ensure supplies of glycerol for use as fuels or chemicals [3]. In addition, the utilization of glycerol to produce value-added secondary products would make biodiesel even more economically feasible.

In recent years, various methods for the production of hydrogen and syngas from glycerol have been considered, steam reforming being the most studied process to date [4]. Other techniques that offer an equally competitive performance have also been reported in the literature. These include pyrolysis [5], dry reforming [6], autothermal reforming [7], aqueous-phase reforming [8] or supercritical water reforming [9]. Conventional heating systems combined with metal-based catalysts are also used in these termal valorization processes. The nature of the metal components has a remarkable influence on the performance as well as on the gas distribution of the products. Ni and noble metal-based catalysts are widely employed in glycerol reforming and detailed reviews on these catalysts can be found elsewhere [10]. The effect of the support (e.g., $\mathrm{Al}_{2} \mathrm{O}_{3}, \mathrm{SiO}_{2}, \mathrm{AC}, \mathrm{MgO}, \mathrm{ZrO}_{2}, \mathrm{CeO}_{2}$ ) on performance and stability has also been reported [11,12]. However, the use of these metal-based catalysts is not without its problems, deactivation of the catalyst due to heavy coke deposition being one of the most important drawbacks.

Alternatively, as was demonstrated in a previous work by our group [13] the microwave pyrolysis of glycerol using carbonbased catalysts is an effective method of producing syngas. It was observed that the use of carbonaceous catalysts improved selectivity towards hydrogen, making it possible to achieve a synthesis gas with a greater $\mathrm{H}_{2} / \mathrm{CO}$ ratio than when no catalyst was used. It was also found that microwave heating ensured a higher gas fraction with an elevated syngas content compared to conventional heating, even at low temperatures $\left(400{ }^{\circ} \mathrm{C}\right)$.

Microwave radiation is known to offer additional advantages over traditional thermal heat sources. First and foremost, it provides a rapid, energy-efficient way of heating materials. Microwaves are also able to promote or accelerate chemical reactions in a way that is not possible in conventional processing by selectively heating the reactants. Thus, microwave heating offers a wide variety of applications in diverse fields [14-16]. Catalytic systems involving metal catalysts and the influence of microwave dielectric heating have been studied extensively in recent years [17]. However, the combination of carbon catalysis and microwave heating is a fairly novel subject [18]. Although carbon 
materials are not frequently used in catalysis, there is increasing interest in this area, as reflected by the increasing number of references to them in the literature $[19,20]$.

In view of the results we obtained previously from the pyrolysis of glycerol by means of microwave heating and carbon-based catalysts [13], the present work is focused on the steam and dry reforming of glycerol under similar pyrolysis conditions. Activated carbon which showed the best performance in the pyrolysis tests was selected as catalyst. The influence of the valorization process and the heating system (electrical vs. microwave heating) on the catalyst performance in terms of glycerol conversion and $\mathrm{H}_{2}$ and syngas yields was studied. In the case of steam reforming, the water/glycerine molar ratio was also taken into consideration.

\section{Experimental}

\subsection{Experimental procedure}

The thermal valorization of glycerol was carried out by means of pyrolysis, steam reforming and dry reforming using different heating systems: an electrical furnace (EF) and a singlemodemicrowave oven (MW). Glycerol, with a purity of $99 \%$, was supplied by Panreac Quimica, S.A. An activated carbon (AC) obtained from bituminous carbon (BC) and activated with steam was used as catalyst, and in the case of microwave heating as catalyst/microwave receptor $(\mathrm{C} / \mathrm{MR})$. The main chemical and textural characteristics of this activated carbon, as well as the inorganic composition of the ashes, are given elsewhere [13]. All the experiments were performed over this activated carbon at $800{ }^{\circ} \mathrm{C}$ and the performance of the catalyst was evaluated in terms of glycerol conversion and $\mathrm{H}_{2}$ and syngas yields.

The liquid glycerol was pumped into a quartz reactor ( $40 \mathrm{~cm}$ length $\times 3 \mathrm{~cm}$ i.d.) at a flow rate of $40 \mathrm{mLh}^{-1}$, by a syringe pump. The reactor was loaded with $12 \mathrm{~g}$ of activated carbon, so that the weight hourly space velocity (WHSV) was the same in all cases $\left(3.33 \mathrm{mLh}^{-1} \mathrm{~g}^{-1}\right)$. During pyrolysis and steam reforming of glycerol the reactor was kept under an inert atmosphere at a nitrogen flow rate of $60 \mathrm{mLmin}^{-1}$. In the case of steam reforming, aqueous solutions of glycerol (molar ratio $\mathrm{H}^{2} \mathrm{O} /$ glycerol $=1,6$ and 9) were used. For dry reforming, the same nitrogen flow was applied until the operating temperature was reached. Then a $\mathrm{CO}_{2}$ flow rate of $60 \mathrm{mLmin}^{-1}$ was introduced. All the experiments were carried outat atmospheric pressure.

In the case of EF, the furnace was previously heated to the corresponding pyrolysis temperature. The reactor loaded with the catalyst was placed inside the EF, and the temperature was monitored by means of a type $\mathrm{R}$ thermocouple which was in constant contact with the load. Once the pyrolysis temperature was reached and stabilized, the thermocouple was taken out of the reactor and the glycerol injector was placed in the same position as that previously occupied by the thermocouple. In the case of MW, the loaded reactor was positioned in the centre of the microwave guide and an infrared optical pyrometer was used to monitor the temperature. The required pyrolysis temperature was reached by varying the microwave power. Tracking the evolution of temperature accurately during the process was extremely problematic due to the difficulties inherent in measuring this parameter in microwave devices [21]. Nevertheless, in the case of the temperature of the bulk activated carbon, the optical 
pyrometer was calibrated for each activated carbon and for each temperature (in separate experiexperiments) by switching off the microwave and placing a thermocouple in the centre of the bulk charge. The emissivity parameter was positioned in the pyrometer in such a way that the temperature measured by both the optical pyrometer and thermocouple was the same. Once the steady state temperature was reached the temperature shown by the optical pyrometer could be expected to give an accurate reading of the average temperature of the bulk activated carbon.

After the system was purged and the temperature had stabilized, the glycerine $/ \mathrm{H}_{2} \mathrm{O} / \mathrm{CO}_{2}$ inlet was activated for $30 \mathrm{~min}$. The volatiles evolved from the pyrolysis of glycerol passed through six consecutive condensers. The first five were empty and placed in an ice bath keeping them refrigerated, while the last one contained magnesium perchlorate (anhidrone) to remove any moisture content. The non-condensable gases were collected in $3 \mathrm{~L}$ Tedlar ${ }^{\circledR}$ bags (with a polypropylene fitting for sampling) every $3 \mathrm{~min}$, so that a total of 10 bags were collected by the end of the experiments. The solid and oil fraction yields were calculated from the weight of each fraction (not including the initial mass of the catalyst), while the gas yield was evaluated by difference.

The gases were analyzed in a Varian CP-3800 gas chromatograph equipped with a thermal conductivity detector (TCD) and two columns connected in series. The first column was a $80 / 100$ Hayesep Q $(2 \mathrm{~m} \times 1 / 8 \mathrm{in} . \times 2 \mathrm{~mm})$, whereas the second column was a $80 / 100$ Molesieve $13 \mathrm{X}(1.5 \mathrm{~m} \times 1 / 8$ in. $\times 2 \mathrm{~mm})$. The second column was bypassed by a six-port valve for the analysis of $\mathrm{CO}_{2}$ and hydrocarbons $\left(>\mathrm{C}_{2}\right)$. The initial oven temperature was $60{ }^{\circ} \mathrm{C}$, which was held for $1.5 \mathrm{~min}$. It was then programmed to rise from 60 to $90{ }^{\circ} \mathrm{C}$ at $30^{\circ} \mathrm{C} / \mathrm{min}$ with the isotherm being held for $2 \mathrm{~min}$. The temperature was then lowered from 90 to $60{ }^{\circ} \mathrm{C}$ at $50{ }^{\circ} \mathrm{C} / \mathrm{min}$ and held for $2 \mathrm{~min}$. The TCD was calibrated at periodic intervals using a standard gas mixture.

\subsection{Data analysis}

Catalytic performance was measured in terms of glycerol conversión to gaseous products and yields of hydrogen and syngas. Other authors [22] believe that the amount of carbon moles in the gas products may be used to evaluate the conversion of glycerol. However, if carbon-based catalysts are used, some of the carbon may find its way into the mixture of gaseous products. For these reasons, glycerol conversion (Eq. (1)) was calculated in different ways depending on the process. In pyrolysis and dry reforming, the conversions were calculated from the number of hydrogen moles found in the gases produced, using Eq. (1). Insteam reforming, blank experiments were performed using an amount of water that corresponded to the different water-to-glycerol molar ratios (WGMRs). The amount of carbon moles produced in the gas products was subtracted from the carbon moles produced in the steam reforming

experiments, in accordance with Eq. (2).

glycerol conversion, $\%=(\mathrm{H}$ moles in gas products $) /(8 \times$ glycerol moles in the feedstock) x 100

glycerol conversion, $\%=\left(\left(\mathrm{C}-\mathrm{C}_{\text {blank }}\right)\right.$ moles in gas products $) /(3 \times$ glycerol moles in the feedstock) x 100 
The $\mathrm{H}_{2}$ and syngas yields were calculated on the basis of Eq. (3) and (4), respectively. The yield is expressed as liters $\left(\mathrm{H}_{2}\right.$ or syngas $)$ per gram in the feedstock at standard conditions for temperature and pressure (STP) to allow comparisons to be made between different sets of experiments:

$\mathrm{H}_{2}$ yield, $(\mathrm{L} / \mathrm{g})=\left(\right.$ litres of $\mathrm{H}_{2}+\mathrm{CO}$ produced $\left.(\mathrm{STP})\right) /\left(\left(\mathrm{C}_{3} \mathrm{H}_{8} \mathrm{O}_{3}+\mathrm{H}_{2} \mathrm{O}+\mathrm{CO}_{2}\right) \mathrm{g}\right.$ in the feedstock)

syngas yield, $(\mathrm{L} / \mathrm{g})=\left(\right.$ litres of $\mathrm{H}_{2}$ produced $\left.(\mathrm{STP})\right) /\left(\left(\mathrm{C}_{3} \mathrm{H}_{8} \mathrm{O}_{3}+\mathrm{H}_{2} \mathrm{O}+\mathrm{CO}_{2}\right) \mathrm{g}\right.$ in the feedstock)

\section{Results and discussion}

The conventional and microwave-assisted pyrolysis of glycerol had been carried out in a previous work [13], using carbon-based catalysts. Of the activated carbons tested, the one which showed the best performance in terms of syngas production was used as catalyst in the steam reforming and dry reforming experiments described below. The influence of the valorization process and the heating system is dealt with in the following sections and the results are compared with those obtained from the previous pyrolysis experiments.

\subsection{Influence of the valorization process}

For the steam reforming of glycerol, different WGMRs were selected (1, 6 and 9). Fig. 1 shows the effect of WGMR on the distribution of the products. With the increase in WGMR, the gas yields decreased by $50 \mathrm{wt} \%$, whereas the liquid fractions rose as a consequence of non-converted water that remained in the condensed reaction products. As for the solid fraction, carbon formed mainly due to the decomposition of hydrocarbons (Reaction (I)), which was favored by the relatively high temperature (i.e., $\left.800^{\circ} \mathrm{C}\right)$ :

$\mathrm{C}_{\mathrm{n}} \mathrm{H}_{2 \mathrm{~m}} \rightarrow \mathrm{m} \mathrm{H}_{2}+\mathrm{n} \mathrm{C}$

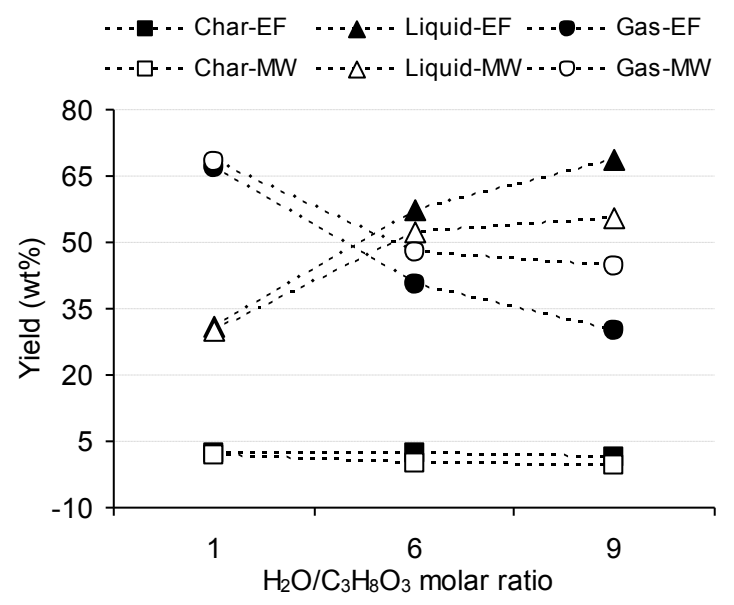

Fig. 1. Product distribution (wt\%) during the steam reforming of glycerol at $800{ }^{\circ} \mathrm{C}$ using different $\mathrm{H}_{2} \mathrm{O} / \mathrm{C}_{3} \mathrm{H}_{8} \mathrm{O}_{3}$ molar ratios, under conventional (EF) and microwave heating (MW). 
Nevertheless, this solid fraction is minimum as a consequence of its gasification by the steam, becoming virtually zero at a $\mathrm{H}_{2} \mathrm{O} / \mathrm{C}_{3} \mathrm{H}_{8} \mathrm{O}_{3}$ molar ratio of 9. Moreover, the char used as a catalyst underwent a slight decrease at higher WGMRs, as a result of the gasification of the carbon atoms (up to $0.66 \mathrm{wt} \%$ for a $\mathrm{H}_{2} \mathrm{O} / \mathrm{C}_{3} \mathrm{H}_{8} \mathrm{O}_{3}$ molar ratio of 9 in the MW). Both $\mathrm{H}_{2} \mathrm{O}$ (Reaction (II)) and $\mathrm{CO}_{2}$ (Reaction (III)) may act as gasifying agents of the carbon deposits and the catalyst, though the former is predominant in the steam reforming experiments.

$\mathrm{C}+\mathrm{H}_{2} \mathrm{O} \leftrightarrow \mathrm{H}_{2}+\mathrm{CO}$

$\mathrm{C}+\mathrm{CO}_{2} \leftrightarrow 2 \mathrm{CO}$

The composition of the gases produced during steam reforming at $800{ }^{\circ} \mathrm{C}$ appears in Table 1. Both $\mathrm{H}_{2}$ and $\mathrm{CO}_{2}$ show a trend that differs from the other gases, i.e. higher WGMRs favor their production, while $\mathrm{CO}, \mathrm{CH}_{4}, \mathrm{C}_{2} \mathrm{H}_{4}$ and $\mathrm{C}_{2} \mathrm{H}_{6}$ decrease in volume. This is due to the splitting of hydrocarbons in the presence of water (Reaction (IV)) and to the water-gas shift reaction (Reaction (V)) since the excess of water favors the displacement of the reactions producing $\mathrm{H}_{2}$ and $\mathrm{CO}_{2}$ :

$$
\begin{aligned}
& \mathrm{C}_{\mathrm{n}} \mathrm{H}_{2 \mathrm{n}+2}+\mathrm{n} \mathrm{H}_{2} \mathrm{O} \leftrightarrow \mathrm{n} \mathrm{CO}+(2 \mathrm{n}+1) \mathrm{H}_{2} \\
& \mathrm{CO}+\mathrm{H}_{2} \mathrm{O} \leftrightarrow \mathrm{CO}_{2}+\mathrm{H}_{2}
\end{aligned}
$$

Table 1. Gas composition (vol.\%) from the steam reforming of glycerol at $800{ }^{\circ} \mathrm{C}$ using different $\mathrm{H}_{2} \mathrm{O} / \mathrm{C}_{3} \mathrm{H}_{8} \mathrm{O}_{3}$ molar ratios (expressed in parenthesis), under conventional (EF) and microwave heating (MW).

\begin{tabular}{lcccccc}
\hline & EF (1) & EF (6) & EF (9) & MW (1) & MW (6) & MW (9) \\
\hline $\mathrm{H}_{2}$ & 30.88 & 34.13 & 38.21 & 40.90 & 46.02 & 49.10 \\
$\mathrm{CO}$ & 47.23 & 45.45 & 44.07 & 43.97 & 43.43 & 42.67 \\
$\mathrm{CO}_{2}$ & 0.64 & 1.43 & 2.03 & 1.48 & 1.92 & 2.09 \\
$\mathrm{CH}_{4}$ & 15.75 & 15.10 & 14.12 & 10.76 & 7.66 & 5.67 \\
$\mathrm{C}_{2} \mathrm{H}_{4}$ & 3.80 & 2.82 & 2.03 & 2.23 & 0.72 & 0.32 \\
$\mathrm{C}_{2} \mathrm{H}_{6}$ & 1.71 & 1.08 & 0.54 & 0.67 & 0.25 & 0.17 \\
$\mathrm{H}_{2}+\mathrm{CO}$ & 78.10 & 79.58 & 82.28 & 84.87 & 89.45 & 91.77 \\
$\mathrm{H}_{2} / \mathrm{CO}$ & 0.7 & 0.8 & 0.9 & 0.9 & 1.1 & 1.2 \\
\hline
\end{tabular}

Furthermore, an increase in theWGMRgenerates higher syngas contents, mainly as a result of the rise in $\mathrm{H}_{2}$, which leads to greater proportions of $\mathrm{H}_{2} / \mathrm{CO}$ in the syngas produced. The decomposition (Reaction (I)) and steam reforming (Reaction (IV)) of hydrocarbons, as well as the simple dehydrogenation reactions (Reaction (VI)) lead to an increase in hydrogen. Carbon monoxide, on the other hand, is reduced through Reaction (V) as the WGMR proceeds: 
$\mathrm{C}_{\mathrm{n}} \mathrm{H}_{2 \mathrm{n}+2} \rightarrow \mathrm{C}_{\mathrm{n}} \mathrm{H}_{2 \mathrm{n}}+\mathrm{H}_{2}$

The performance of this catalyst which is reflected in the glycerol conversion and hydrogen and syngas yields is depicted in Table 2. A lower conversion of glycerol was obtained with the rise in WGMR, probably due to the effect of dilution. As for the $\mathrm{H}_{2}$ and syngas yields, different trends were observed depending on the point of reference. If the amount of glycerol fed in was used as point of reference, the $\mathrm{H}_{2}$ and syngas yields increase with the rise in WGMR, but if the global amount of liquid fed in (i.e. glycerol and water) is taken as the reference, these yields decrease as the WGMR increases. In relation to the global feed, it is significant that the decrease in syngas yield with the rise in WGMR is greater than the fall in $\mathrm{H}_{2}$ yield. This occurs because most of the $\mathrm{H}_{2}$ in the gas comes from the water rather than from the glycerol, as WGMR increases. This may have unfavorable consequences if the main objective is the maximum conversion of glycerol to $\mathrm{H}_{2}$ and syngas, rather than the conversion of water.

Table 2. Conversion of glycerol to gaseous products and yields of hydrogen and syngas at $800{ }^{\circ} \mathrm{C}$ using different $\mathrm{H} 2 \mathrm{O} / \mathrm{C} 3 \mathrm{H} 8 \mathrm{O} 3$ molar ratios (expressed in parenthesis), under conventional (EF) and microwave heating (MW).

\begin{tabular}{lcccccc}
\hline & EF (1) & EF (6) & EF (9) & MW (1) & MW (6) & MW (9) \\
\hline $\begin{array}{l}\text { Conversion } \\
(\%)\end{array}$ & 67.8 & 63.4 & 52.3 & 70.4 & 64.4 & 62.3 \\
$\begin{array}{l}\mathrm{H}_{2} \text { yield } \\
\left(\mathrm{mol} \mathrm{H}_{2} / \mathrm{mol} \mathrm{C}_{3} \mathrm{H}_{8} \mathrm{O}_{3}\right)\end{array}$ & 1.25 & 1.52 & 1.51 & 1.88 & 2.86 & 3.72 \\
$\begin{array}{l}\mathrm{H}_{2} \text { yield } \\
\left(\mathrm{L}_{\mathrm{cs}} \mathrm{H}_{2} / \mathrm{g} \text { feed) }\right.\end{array}$ & 0.25 & 0.17 & 0.13 & 0.38 & 0.32 & 0.30 \\
$\begin{array}{l}\text { Syngas yield } \\
\left(\mathrm{L}_{\text {STP syngas/g }} \mathrm{C}_{3} \mathrm{H}_{8} \mathrm{O}_{3}\right)\end{array}$ & 0.77 & 0.88 & 0.84 & 0.95 & 1.36 & 1.70 \\
$\begin{array}{l}\text { Syngas yield } \\
\left(\mathrm{L}_{\text {STP syngas/g feed })}\right.\end{array}$ & 0.64 & 0.40 & 0.30 & 0.79 & 0.62 & 0.61 \\
\hline
\end{tabular}

The steam reforming experiments with the lowest WGMR, i.e. value of 1 , were selected because they produced the highest conversion of glycerol to gaseous products, the lowest liquid residue and the highest $\mathrm{H}_{2}$ and syngas yields (using the global feed as reference). They were then compared with the results of the pyrolysis and dry reforming experiments. According to the distribution of the products (Table 3), in all of the processes the highest fraction corresponds to the gaseous products, followed by the liquid and then the solid yields. The main differences appear in the steam reforming of glycerol, where the lowest and highest fractions of gases and liquids are produced, respectively. These differences are due to the amount of water that remains in the oil, as the gas yield is calculated by difference. When the results of the pyrolysis and dry reforming experiments were compared, no significant differences were found, except that the highest gas fraction was produced in MW-DR (up to $86 \mathrm{wt} \%$ ). 
Table 3. Products distribution (wt $\%$ ) from the thermal valorization of glycerol at 800 ${ }^{\circ} \mathrm{C}$, under conventional (EF) and microwave heating (MW).

\begin{tabular}{lcccccc}
\hline & EF-P & MW-P & EF-SR & MW-SR & EF-DR & MW-DR \\
\hline Char & 1.4 & 3.7 & 2.3 & 1.7 & 2.1 & 1.9 \\
Liquid & 16.8 & 12.7 & 30.8 & 30.1 & 18.4 & 12.5 \\
Gas & 81.8 & 83.6 & 66.8 & 68.1 & 79.8 & 85.6 \\
\hline
\end{tabular}

Examination of the composition of the gases evolved during the experiments (Table 4) shows that the synthesis gas produced is higher than 73 vol.\% in all cases. Other gases, such as $\mathrm{CO}_{2}$ and light hydrocarbons $\left(\mathrm{CH}_{4}, \mathrm{C}_{2} \mathrm{H}_{4}\right.$ and $\left.\mathrm{C}_{2} \mathrm{H}_{6}\right)$, were also detected. The most successful method for producing hydrogen was steam reforming, which displayed the highest values of $\mathrm{H}_{2}+\mathrm{CO}$ in the final gas composition ( $85 \mathrm{vol} . \%$ ). Pyrolysis was the second best process producing up to $81 \mathrm{vol} \%$ of syngas, followed by dry reforming (79 vol.\%). It is significant that the process with the lowest gas fraction generates the highest hydrogen and syngas yields, and vice versa, corresponding to the steam and dry reforming, respectively. If we look at the stoichiometric reactions in the decomposition of glycerol (Reaction (VII)) and the steam reforming of glycerol (Reaction (VIII)), we will observe a higher $\mathrm{H}_{2}$ content in the latter due to the donation of $\mathrm{H}_{2}$ by the water:

$$
\begin{aligned}
& \mathrm{C}_{3} \mathrm{H}_{8} \mathrm{O}_{3} \rightarrow 4 \mathrm{H}_{2}+3 \mathrm{CO} \\
& \mathrm{C}_{3} \mathrm{H}_{8} \mathrm{O}_{3}+3 \mathrm{H}_{2} \mathrm{O} \rightarrow 7 \mathrm{H}_{2}+3 \mathrm{CO}_{2}
\end{aligned}
$$

Table 4. Gas composition (vol.\%) from the thermal valorization of glycerol at $800{ }^{\circ} \mathrm{C}$, under conventional (EF) and microwave heating (MW).

\begin{tabular}{lcccccc}
\hline & EF-P & MW-P & EF-SR & MW-SR & EF-DR & MW-DR \\
\hline $\mathrm{H}_{2}$ & 28.91 & 34.60 & 30.88 & 40.90 & 28.32 & 33.84 \\
$\mathrm{CO}$ & 48.75 & 45.93 & 47.23 & 43.97 & 45.02 & 45.20 \\
$\mathrm{CO}_{2}$ & 1.44 & 1.80 & 0.64 & 1.48 & 7.16 & 6.13 \\
$\mathrm{CH}_{4}$ & 14.61 & 13.52 & 15.75 & 10.76 & 13.59 & 10.49 \\
$\mathrm{C}_{2} \mathrm{H}_{4}$ & 4.27 & 2.96 & 3.80 & 2.23 & 4.31 & 3.57 \\
$\mathrm{C}_{2} \mathrm{H}_{6}$ & 1.82 & 1.03 & 1.71 & 0.67 & 1.60 & 0.77 \\
$\mathrm{H}_{2}+\mathrm{CO}$ & 77.66 & 80.53 & 78.10 & 84.87 & 73.34 & 79.04 \\
$\mathrm{H}_{2} / \mathrm{CO}$ & 0.6 & 0.8 & 0.7 & 0.9 & 0.6 & 0.7 \\
\hline
\end{tabular}

From the gas composition obtained during the thermal processes, it can be seen that $\mathrm{CO}$, $\mathrm{H}_{2}$ and $\mathrm{CH}_{4}$ were the main gases produced in that order. However, $\mathrm{CO}_{2}$ is influenced by the process itself and so the largest amounts (up to 7 vol.\%) correspond to the dry reforming experiments, as was to be expected. Light hydrocarbons like $\mathrm{C}_{2} \mathrm{H}_{4}$ and $\mathrm{C}_{2} \mathrm{H}_{6}$ 
appear in proportions below 5 vol.\% and 2 vol.\%, respectively, in the different experiments. These gas compositions differ from those obtained by other authors who studied similar processes using metal-based catalysts [6,11,22]. What is of particular interest are the lower $\mathrm{CO}_{2}$ and higher $\mathrm{CO}$ yields obtained under our experimental conditions. Gasification with carbon dioxide is an important factor when using carbonbased catalysts since more carbon atoms are involved in the production of CO. However, the presence of potassium in the activated carbon [13] may also play a role in the gasification reaction [23]. Nevertheless, carbon-based catalysts seem to be ideal for producing synthesis gas with a $\mathrm{H}_{2} / \mathrm{CO}$ ratio close to 1 . They also offer the advantage of minimal $\mathrm{CO}_{2}$ emissions.

On the other hand, the amount of $\mathrm{CH}_{4}$ produced by far exceeds the yields reported in the literature [6,11], and explains the lower $\mathrm{H}_{2}$ yields. This may suggest that carbon-based catalysts did not catalyze the methane steam (Reaction (IX)) and dry reforming (Reaction $(\mathrm{X})$ ) effectively enough for hydrogen production to take place. From a practical point of view, a small amount of methane in the reformate may be tolerated since methane can be burned to provide the heat necessary for the endothermic reforming reaction, as occurs with unused hydrogen in a fuel cell [11].

$$
\begin{aligned}
& \mathrm{CH}_{4}+\mathrm{H}_{2} \mathrm{O} \leftrightarrow 3 \mathrm{H}_{2}+\mathrm{CO} \\
& \mathrm{CH}_{4}+\mathrm{CO}_{2} \leftrightarrow 2 \mathrm{H}_{2}+2 \mathrm{CO}
\end{aligned}
$$

The conversion of glycerol to gaseous products in the different processes is presented in Table 5. The greatest value is displayed by dry reforming, followed by steam reforming and pyrolysis. Reforming processes that employ different agents tend to use up more glycerol than when only thermal decomposition occurs. In the case of the $\mathrm{H}_{2}$ and syngas yields, some interesting differences come to light when the glycerol feed is taken as reference. The steam reforming experiments produced the highest $\mathrm{H}_{2}$ and syngas yields due to the $\mathrm{H}_{2}$ donated by the water, the values corresponding to the gas yield being the lowest. Dry reforming was the process that generated the highest gas fraction with the lowest $\mathrm{H}_{2}$ and syngas yields in the final gas composition. However, if the $\mathrm{H}_{2}$ and syngas yields are considered from the point of view of number of glycerol units introduced ( $\mathrm{g}$ or moles), the dry reforming experiments take a second place as a result of the higher conversions of glycerol in comparison with pyrolysis. Moreover pyrolysis has the lowest $\mathrm{H}_{2}$ yield since only glycerol (with the lowest conversions) contributes to the presence of $\mathrm{H}_{2}$ in the gas fraction. When the global feed is taken as the point of reference, no significant differences between the different processes were found. Finally the syngas yield in the pyrolysis under EF is $10 \%$ higher than in the reforming processes as a result of the higher gas yield obtained in the pyrolysis experiments.

Table 5. Conversion of glycerol to gaseous products and yields of hydrogen and syngas during the thermal valorization of glycerol at $800{ }^{\circ} \mathrm{C}$, under conventional $(\mathrm{EF})$ and microwave heating (MW).

\begin{tabular}{lcccccc}
\hline & EF-P & MW-P & EF-SR & MW-SR & EF-DR & MW-DR \\
\hline $\begin{array}{l}\text { Conversion } \\
(\%)\end{array}$ & 62.1 & 70.4 & 67.8 & 70.4 & 70.9 & 75.6 \\
$\mathrm{H}_{2}$ yield & 1.12 & 1.38 & 1.25 & 1.88 & 1.17 & 1.59 \\
\hline
\end{tabular}




\begin{tabular}{lcccccc}
\hline$\left(\mathrm{mol} \mathrm{H}_{2} / \mathrm{mol} \mathrm{C}_{3} \mathrm{H}_{8} \mathrm{O}_{3}\right)$ & & & & & & \\
$\begin{array}{l}\mathrm{H}_{2} \text { yield } \\
\left(\mathrm{L}_{\mathrm{cs}} \mathrm{H}_{2} / \mathrm{g} \text { feed }\right)\end{array}$ & 0.27 & 0.34 & 0.25 & 0.38 & 0.25 & 0.34 \\
$\begin{array}{l}\text { Syngas yield } \\
\left(\mathrm{L}_{\text {STP syngas }} / \mathrm{g} \mathrm{C}_{3} \mathrm{H}_{8} \mathrm{O}_{3}\right)\end{array}$ & 0.73 & 0.79 & 0.77 & 0.95 & 0.73 & 0.99 \\
$\begin{array}{l}\text { Syngas yield } \\
\left(\mathrm{L}_{\text {STP syngas } / g \text { feed })}\right.\end{array}$ & 0.73 & 0.79 & 0.64 & 0.79 & 0.65 & 0.80 \\
\hline
\end{tabular}

\subsection{Influence of the heating system}

It was found thatMWgenerates greater gas fractions and lower liquid yields, while the carbonaceous residue decreases only in the reforming experiments (Fig. 1 and Table 3 ). The decrease in solid yield observed in the steam and dry reforming experiments shows that $\mathrm{H}_{2} \mathrm{O}$ is more efficient as gasifying agent than $\mathrm{CO}_{2}$.

The formation of the gaseous components is known to be a consequence of tar cracking, the decomposition of char at high temperatures and the reactions (both homogeneous and heterogeneous) between the species formed during the process. In previous works by our group [24] it was found that microwave heating favors heterogeneous reactions, which explains the higher values of gaseous products under MW.

As for the gas compositions obtained during the thermal processes (Tables 1 and 4), MW yields higher $\mathrm{H}_{2}$ values in all cases. The lower volumes of light hydrocarbons $\left(\mathrm{CH}_{4}, \mathrm{C}_{2} \mathrm{H}_{4}\right.$ and $\left.\mathrm{C}_{2} \mathrm{H}_{6}\right)$ detected under MW suggest that decomposition reactions are favored with this kind of heating [24], resulting in the presence of hydrogen in the final gas composition. Moreover, the Fe, the basic oxides [13] and the active centres on the surface of the activated carbon are known to catalyze the methane decomposition reaction (Reaction $(\mathrm{XI}))[24]$ :

$\mathrm{CH}_{4} \rightarrow 2 \mathrm{H}_{2}+\mathrm{C}$

Furthermore, it was observed that MW heating promotes higher conversions of glycerol to gaseous products as well as higher $\mathrm{H}_{2}$ yields (see Tables 2 and 5), regardless of the point of reference adopted (glycerol or global feed). In short, microwave-assisted processes give rise to higher syngas yields and $\mathrm{H}_{2} / \mathrm{CO}$ ratios.

\section{Conclusions}

Reforming processes that employ $\mathrm{CO}_{2}$ or $\mathrm{H}_{2} \mathrm{O}$ promote higher glycerol conversions than thermal decomposition, in that order. In the case of the $\mathrm{H}_{2}$ and syngas yields, the point of reference (glycerol or global feed) assumes special significance. Steam reforming gives the highest $\mathrm{H}_{2}$ and syngas yields for both references due to the $\mathrm{H}_{2}$ donated by the water, although non-converted water that remains in the condensed reaction products reduces the final gas yield. The water-to-glycerin molar ratio seems to be a critical factor in the performance of steam reforming since, as this increases, the conversion of glycerol to gaseous products decreases, while the liquid residue increases. In the final gas composition, dry reforming produces the lowest amount of $\mathrm{H}_{2}$ and 
syngas. However, if the $\mathrm{H}_{2}$ and syngas yields are estimated by the units of glycerol introduced ( $\mathrm{g}$ or moles), the dry reforming experiments take second place, as a result of higher conversions of glycerol achieved compared to those of the pyrolysis experiments. The latter show the lowest $\mathrm{H}_{2}$ yields since only glycerol (with the lowest conversions) contributes to the presence of $\mathrm{H}_{2}$ in the gas fraction. When the global feed is selected as point of reference, no significant differences between the different processes were observed. It was found that microwave processing promotes higher conversions of glycerol to gaseous products as well as higher $\mathrm{H}_{2}$ and syngas yields compared to conventional heating processes in all the cases studied. Also carbon-based catalysts appear to be the most suitable catalysts for producing synthesis gas with a $\mathrm{H}_{2} / \mathrm{CO}$ ratio close to 1 . What is more, they produce only very small amounts of $\mathrm{CO}_{2}$.

\section{Acknowledgements}

Y.F. and J.M.B. are grateful to CSIC of Spain and the European Social Fund (ESF) for financial support under the I3P and JAE programmes, respectively.

\section{References}

[1] European Biodiesel Board, Statistics 2008: http://www.ebb-eu.org/stats.php [accessed 23.10.09].

[2] S. Claude, Fett/Lipid 101 (1999) 101.

[3] A. Behr, J. Eilting, K. Irawadi, J. Leschinskin, F. Lindner, Green Chem. 10 (2008) 13.

[4] S. Adhikari, S.D. Fernando, S.D. Filip To, R.M. Bricka, P.H. Steele, A. Haryanto, Energ. Fuels 22 (2008) 1220.

[5] T. Valliyappan, N.N. Bakhshi, A.K. Dalai, Bioresour. Technol. 99 (2008) 4476.

[6] X. Wang, M. Li, MWang, H. Wang, S. Li, S. Wang, X. Ma, Fuel 88 (2009) 2148.

[7] H. Wang, X. Wang, M. Li, S. Li, S. Wang, X. Ma, Int. J. Hydrogen Energ. 34 (2009) 5683.

[8] N. Luo, X. Fu, F. Cao, T. Xiao, P.P. Edwards, Fuel 87 (2008) 3483.

[9] A.J. Byrd, K.K. Pant, R.B. Gupta, Fuel 87 (2008) 2956.

[10] S. Adhikari, S.D. Fernando, A. Haryanto, Energ. Convers. Manage. 50 (2009) 2600 .

[11] B. Zhang, X. Tang, Y. Li, Y. Xu, W. Shen, Int. J. Hydrogen Energ. 32 (2007) 2367.

[12] W. Suprun, M. Lutecki, T. Haber, H. Papp, J. Mol. Catal. A: Chem. 309 (2009) 71.

[13] Y. Fernández, A. Arenillas, M.A. Díez, J.J. Pis, J.A. Menéndez, J. Anal. Appl. Pyrol. 84 (2009) 145.

[14] D.A. Jones, T.P. Lelyveld, S.D. Mavrofidis, S.W. Kingman, N.J. Miles, Resour. Conserv. Recy. 34 (2002) 75.

[15] X. Zhang, D.O. Hayward, Inorg. Chim. Acta 359 (2006) 3421.

[16] F. Marken, U.J. Sur, B.A. Coles, R.G. Compton, Electrochim. Acta 51 (2006) 2195.

[17] M. Larhed, C. Moberg, A. Hallberg, Acc. Chem. Res. 35 (2002) 717.

[18] J.A. Menéndez, A. Arenillas, B. Fidalgo, Y. Fernández, L. Zubizarreta, E.G. Calvo, J.M. Bermúdez, Fuel Process. Technol. (2009), doi:10.1016/j.fuproc. 2009.08.021.

[19] M.F.R. Pereira, J.J.M. Órfão, J.L. Figueiredo, Appl. Catal. A 184 (1999) 153.

[20] N. Muradov, F. Smith, A. T-Raissi, Catal. Today 102-103 (2005) 225. 
[21] J.A. Menéndez, E. Menéndez, A. García, J.B. Parra, J.J. Pis, J. Microwave Power EE 34 (1999) 137.

[22] I.N. Buffoni, F. Pompeo, G.F. Santori, N.N. Nichio, Catal. Commun. 10 (2009) 1656.

[23] M.J. Height, J.B. Howard, J.W. Tester, J.B. Vander, J. Phys. Chem. 109 (2005) 12337.

[24] A. Domínguez, Y. Fernández, B. Fidalgo, J.J. Pis, J.A. Menéndez, Energ. Fuel 21 (2007) 2006. 